\title{
Use of nanofiltration membrane technology for ceramic industry wastewater treatment
}

\author{
R. MOlineR-SAlVADOR (1), A. DERATANi (2), J. PALMERI (3), E. SÁNCHEZ (1),
}

\begin{abstract}
(1) Instituto de Tecnología Cerámica. Asociación de Investigación de las Industrias Cerámicas. Universitat Jaume I. Castellón. Spain (2) Institut Européen des Membranes, UMR CNRS-ENSCM-Université Montpellier 2, 34095 Montpellier, France

(3) Laboratoire de Physique Theorique, UMR CNRS-Université Paul Sabatier, 31062 Toulouse, France
\end{abstract}

Este trabajo ha sido presentado como comunicación oral, tras su evaluación por el Comité Científico, en el XII Foro Global del Recubrimiento Cerámico. QUALICER (13 y 14 febrero 2012. Castellón. España).

\begin{abstract}
A study has been undertaken of an advanced wastewater treatment approach using polymer nanofiltration membranes, in an attempt to obtain water of sufficient quality to allow it to be reused in the same production process or, alternatively, to be discharged without any problems. The study has initially focused on the removal of organic matter (reduction of COD) and the most representative ions present in the wastewater, such as $\mathrm{Na}^{+}, \mathrm{Mg}^{2+}, \mathrm{Cl}$, and $\mathrm{SO}_{4}^{2-}$.

In a first part of the study, with a view to optimising the experimental phase, a simulation has been performed of the nanofiltration process using the NanoFlux software. Among other things, the simulation allows the most suitable membranes to be selected as a function of the permeate flow rate and desired level of retention in the substances to be removed. The subsequent experimentation was carried out in a laboratory tangential filtration system that works with flat membranes. It was found that retention values of about $90 \%$ were obtained for the studied substances, with a good permeate flow rate, using low operating pressures. These results demonstrate the feasibility of the studied technology and its potential as a treatment for improving ceramic industry wastewater quality.
\end{abstract}

Key words: Nanofiltration, Membrane, Wastewater, Ceramic Tiles Industry, Red/White Ceramics

Uso de la tecnología de nanofiltración a través de membranas para el tratamiento de aguas residuales de la industria cerámica

Este estudio ha sido emprendido con el fin de acercar la nanofiltración a través de membranas poliméricas al tratamiento de las aguas residuales industriales de la industria cerámica, esperando obtener un agua con la suficiente calidad como para ser reutilizada en el propio proceso productivo o, alternativamente, poder verterla. El estudio se ha centrado en la eliminación de materia orgánica (reducción de D.Q.O) y algunos iones presentes en las aguas residuales, tales como $\mathrm{Na}^{+}, \mathrm{Mg}^{2+}, \mathrm{Cl}^{-}$y SO${ }_{4}^{2-}$. En primer lugar, se ha realizado una simulación del proceso de nanofiltración usando el software NanoFlux. Entre otras cosas, la simulación permite seleccionar las membranas más apropiadas en función del caudal de permeado obtenido y en función del nivel de retención de la sustancia que se desea eliminar. En una segunda parte, se realizaron los ensayos experimentales en un sistema de laboratorio de filtración tangencial que trabaja con membranas planas.

La retención obtenida para las sustancias estudiadas es de aproximadamente el $90 \%$. Todo ello, con un buen caudal de permeado y usando bajas presiones de trabajo. Estos resultados demuestran la viabilidad de la tecnología y su potencial como tratamiento para mejorar la calidad de las aguas residuales de esta industria.

Palabras Clave: Nanofiltración, Membrana, Aguas Residuales, Baldosas Cerámicas, Cerámica Roja/Blanca.

\section{INTRODUCTION}

Water management has become an increasingly critical issue in most traditional industrial sectors, owing to the large quantities of wastewater they produce. In the case of the ceramic tile industry, most of the wastewater arises in the washing operations of the facilities used for the preparation and application of glazes and other coatings. In addition, a considerable amount of groundwater is used as the fresh water source for glaze and other coatings preparation. However as the groundwater resource becomes more and more limited, ceramic industry has to find solution to lower its groundwater consumption. One possibility is, for instance, to use recycled water in glazing operations.

The composition of these ceramic industry wastewaters varies widely and may include suspended solids and electrolytes of very different nature, as well as organic substances that mostly come from the additives used in decorating the tiles. However, the treatment techniques that are currently used (generally physico-chemical treatments) are not entirely effective, in particular with regard to nonbiodegradable organic compounds that increase the water 
COD, certain ions such as alkaline and alkaline-earth cations, boron compounds, chlorides, sulphates, etc. This inadequate wastewater treatment makes it impossible to reuse this water in the same production process and may even impede water discharge. As a result, this water needs external handling or additional treatment, entailing high economic costs and/or environmental impact.

Membrane technology is an advanced method of water treatment. It has been demonstrated that ions and molecules can be selectively removed from polluted waters using membrane processes. Selection of the appropriate membrane suitable to address the desired separation is determined by the feed composition of water to be treated and the objective of purification to be reached, as well. Nanofiltration (NF), which has recently been developed, presents significant advantages on comparing with other membrane processes. NF process allows an almost complete removal of multivalent ions and of relatively small organic compounds, and a good rejection of monovalent ions depending on the membrane and the operating conditions while it requires lower operating pressure than reverse osmosis (RO).

In this work it is proposed to make a preliminary evaluation of the application of nanofiltration technique to wastewaters from the ceramic tile industry with a view to removing organic matter (reducing COD) as well as dissolved salts in order to enhance the reuse of treated water in the ceramic industry. Boron compounds were not included in the study because the wastewater containing these needs to undergo a pre-treatment. Efficient purification has to decrease the organic pollution and the total dissolved salts (TDS) under a certain limit that can be estimated for the most commonly cleaning uses to be about $50 \mathrm{mg} \mathrm{O} / 1$ for COD and $500 \mathrm{mg} / 1$ for TDS. This objective can be, in principle, readily obtained using a NF stage.

\section{METHODOLOGY}

\subsection{Membrane processes in water treatment}

Purification of water by treatments using membrane materials began to be important in 60's because of the good performances that offered synthetic membranes. Membrane separation process has the following advantages: costly efficient, environmentally benign and clean technology since no additional chemicals are needed, easy to operate and not much sensitive to composition variability, allowing the production of high quality water. Nevertheless, it has been in the last years when the membrane treatment has begun to be applied in the wastewater purification. The development of membrane technology to new applications has been the result of numerous advances in the field of membranes elaboration.

A membrane can be defined as a selective barrier that separates two phases. From this definition it appears that transport of species from upstream to downstream is restricted in a selective manner due to differences in physical and/or chemical properties between the membrane and the permeating species (1). Dissolved solids and compounds in the feed phase can then be totally or partially retained in retentate, whereas permeate will be free of compounds rejected by the membrane. Shape, size and charge are the main characteristics that determine membrane rejection. Different driving forces such as pressure, electrical field, and concentration gradient can originate the transport through the membranes, the pressure driven processes being the most developed in the case of water membrane treatment. The following section will describe the different types of pressure driven membrane processes commonly used in water treatment.

\subsubsection{CLASSIFICATION OF MEMBRANE PROCESSES IN WATER TREATMENT}

As previously outlined, membrane can act as a sieving barrier. The selective transport across the membrane is then mainly governed from the ratio between the size of dissolved species and that of the membrane pores. The following classification in membrane processes can arise depending on the membrane pore radius size $\left(r_{p}\right)$ : microfiltration, ultrafiltration, nanofiltration and reverse osmosis. (Fig 1)

Microfiltration (MF) membranes have the $r_{p}$ ranging from 0.1 to $10 \mu \mathrm{m}$ and the largest membrane permeability. In MF process the applied pressure is low (from 0.2 to 1 bar) and the components are retained by a sieving mechanism. Consequently only components with a size higher than the membrane pore size are retained. MF membranes typically reject suspended solids, large particles, colloids and some micro organisms as bacteria. MF membranes are the far most widely used membrane process with the main applications of clarification, disinfection and as an efficient pre-treatment for further membrane treatment steps.

Ultrafiltration (UF) membranes have smaller $r_{p}$ (from 2 to $100 \mathrm{~nm}$ ) and lower permeability than MF membranes. This feature implies that UF process requires higher operating pressures (from 0.5 to 5 bar) than MF process. In this case, sieving mechanisms are also mainly involved for rejecting the feed components. These membranes can retain small bacteria, viruses and soluble macromolecules such as proteins.

NF process (NF) is an intermediate technique between $\mathrm{UF}$ and reverse osmosis ( $\mathrm{RO}$ ) that has been more recently developed. NF membranes have $r_{p}$ smaller than $2 \mathrm{~nm}$. In this case interactions in addition to steric hindrance take place due to the small size of membrane pores. Thus the transport mechanism is mainly described by sieving and electric (Donnan exclusion) effects among others. There is equilibrium between the charged membrane and the solution. For this reason a lot of ionic species are rejected, even species with size smaller than that of membrane $r_{p}$.

Finally, the RO membranes consist in a dense barrier without predefined pores. The transport mechanism is therefore completely different and is believed to occur according to a solution-diffusion mechanism (2-3). It results that permeability is much lower in this case than for the above mentioned membranes. On the other hand, rejection of the charged solutes contained in the feed solution is almost complete. It should be noted that $\mathrm{RO}$ usually requires high pressures (up to 120 bar) depending of the osmotic pressure of the feed solution that makes this technique quite energy consuming.

\subsubsection{NANOFILTRATION}

As seen in Fig. 1, NF is a technique of separation by membranes located between RO and UF. Initially it was included with $\mathrm{RO}$ but today it is regarded as a different 
technique considering that the transport involves an actually different mechanism as outlined before.

NF is mainly characterized by a transport mechanism based not only on steric hindrance but also according to the solute charge with the following implications:

- Neutral solutes are rejected according to the sieving effect due to the membrane pore size

- A selective separation takes place between readily rejected multivalent ions and partially rejected monovalent ions

- A part of charged species are transported across the membrane decreasing the osmotic pressure.

- The operating pressures are lower (3 to 20 bars) than those used in $\mathrm{RO}$ and higher permeate rate are obtained with this technique leading to a more energy efficiency compared to RO.

This technique can be applied in a lot of sectors such as biotechnology and food industry for extraction and purification of valuable low molecular weight compounds, water and wastewater treatment for the drinking water production and the environmental protection (4).

\subsection{NanoFlux}

NanoFlux $(5,6)$ is a computer simulation program developed in the European Institute of Membranes in Montpellier (France) to model solute transport in the NF range (and in some cases, loose RO and tight UF). It can be used to characterize NF membranes and also predict their performance vis-à-vis complex mixtures of neutral molecules and ions. This program allows one to calculate, starting from standard feed input data, all the necessary NF process output (ionic and molecular rejection, or passages, fluxes,...) from the level of a single membrane element up to that of multi-module/ multi-stage plants. It is possible to obtain quick and reliable simulation results thanks to both the powerful and robust computational algorithms incorporated into the program and the internal NanoFlux database that contains the principal commercial membranes. NanoFlux is also easy to use, thanks to its ergonomic graphical user interface and has been tested and validated using real case studies (5-7). Periodic additions are made and up-dates to the NanoFlux database performed in order to follow technical and market evolutions. This modeling program is thus a powerful aid in decision-making and innovation, when it comes to economically choosing the right membrane and optimizing nanofiltration processes. It can also be used to minimize significantly difficult and costly pilot studies, thereby reducing the total cost and time needed to choose the appropriate membrane and to scale-up and operate NF plants.

The modeling method used in NanoFlux consists in first estimating the pore size from the rejection of model neutral solutes $(5,6)$. A membrane-salt characterization step by studying the rejection of a limited number of simple salts $\left(\mathrm{NaCl}, \mathrm{MgSO}_{4}, \mathrm{Na}_{2} \mathrm{SO}_{4}, \mathrm{CaCl}_{2}\right)$ is to be subsequently carried out. The experimental results for these 1:1, 2:2, 1:2, 2:1 $\left(\left|z_{\text {cation }}\right|,\left|z_{\text {anion }}\right|\right)$ salts are analyzed using NanoFlux via a numerical fitting procedure in order to determine the optimal values of the two parameters (effective membrane charge density and thickness) that characterize the membrane/ salt pair. Theoretical ion rejection predictions for electrolyte solutions are obtained by solving numerically the "Hindered Transport" Extended Nernst-Planck ion flux equations. The best fit parameter values, which minimize the difference between the experimental and theoretical rejections, vary as a function of the salt concentration and $\mathrm{pH}$ of the feed. This analysis allows us to create the internal NanoFlux database. The effective membrane charge and effective thickness for ion mixtures are then determined as a function of feed solution $\mathrm{pH}$, ionic strength and composition using the single salt database combined with an interpolation and weighting

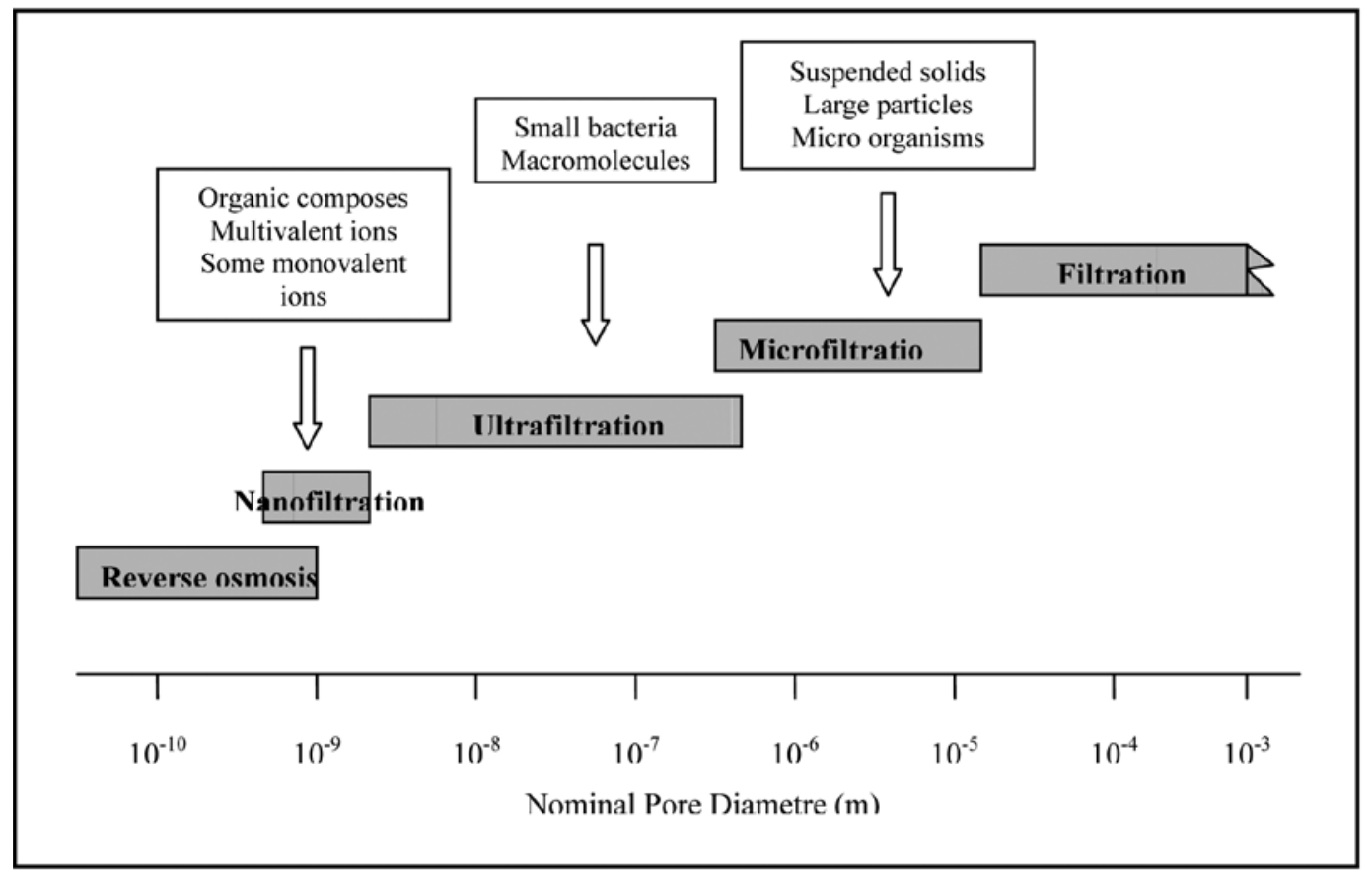

Fig. 1 Classification of membrane treatments 
scheme. The rejection and solution flux of complex multielectrolyte mixtures can be well predicted using the internal single salt database $(5,6)$. NanoFlux can therefore be at the basis of a combined experimental and theoretical method for characterizing, simulating, and optimizing the performance of charged nanofilters.

NanoFlux attempts to fill in a gap in methods for predicting and optimizing NF performance that has arisen due to the complexity of the fundamental ion transport processes and has most likely slowed the widespread industrial development of NF.

\subsection{Method}

\subsubsection{APPARATUS}

The filtration pilot plant (Fig. 2) used for NF experiments consists of a Sepa CF II labscale 316 SS cell system [10], a feed tank [3] with a stainless steel immersed coil [5] and a volumetric pump [8] (cat pump 231, constant flow $9 \mathrm{~L} / \mathrm{min}$ ). The closed loop of the feed solution is made of resisting tubing to high temperature (up to $60^{\circ} \mathrm{C}$ ) and pressure (up to 20 bar).

The feed solution is heated or cooled in the 30 litres feed tank by a circulating thermal bath [1] (Frigitherm-10 P-Selecta) by means of the immerged coil. The temperature feed tank is measured and controlled by an external PT100 Prosensor probe [4] immerged in the feed solution. The retentate temperature when it circulates back to the feed tank is also measured. The pressure of the feed solution and the retentate, modified by the valve [11], are given by pressure gauges [9]. The permeate mass is measured by a balance [12] (Sartorius CP323S) at steady state and the mass flux calculated is registered in a computer [13] via an RS232 output.

\subsubsection{MEMBRANES}

In this study DOW FILMTEC membranes have been used. These membranes are flat and have an effective surface area of $133 \mathrm{~cm}^{2}$. NanoFlux prediction and preliminary tests showed that the NF-90 membrane was the most suitable for our application. The obtained data were then compared to those obtained for another membrane NF-200. Specifications given by the manufacturer for these two membranes are gathered in the table I.

TABLE I. SPECIFICATIONS OF THE NF MEMBRANES GIVEN BY THE MANUFACTURER

\begin{tabular}{|c|c|c|}
\hline Membrane & $\begin{array}{c}\text { Permeate Flow Rate } \\
\left(\mathbf{L} / \mathbf{( h ~}^{\mathbf{2}} \text { bar) }\right.\end{array}$ & $\begin{array}{c}\text { Stabilized Salt } \\
\text { Rejection } \\
(\boldsymbol{\%})\end{array}$ \\
\hline NF-90 & 8,68 & $>97$ \\
\hline NF-200 & 5,99 & 97 \\
\hline
\end{tabular}

Note: Permeate flow and salt rejection based on the following test conditions:

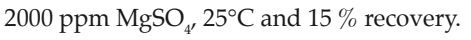

Permeate flows for individual elements may vary by $-15 \% /+50 \%$

\subsubsection{EXPERIMENTAL PROCEDURE}

The approach used consists of two stages:

- Prediction of the membrane performances for NF of the studied wastewater (simplified composition) using NanoFlux. This stage allowed us to select the more appropriate membrane and operating conditions for the second stage.

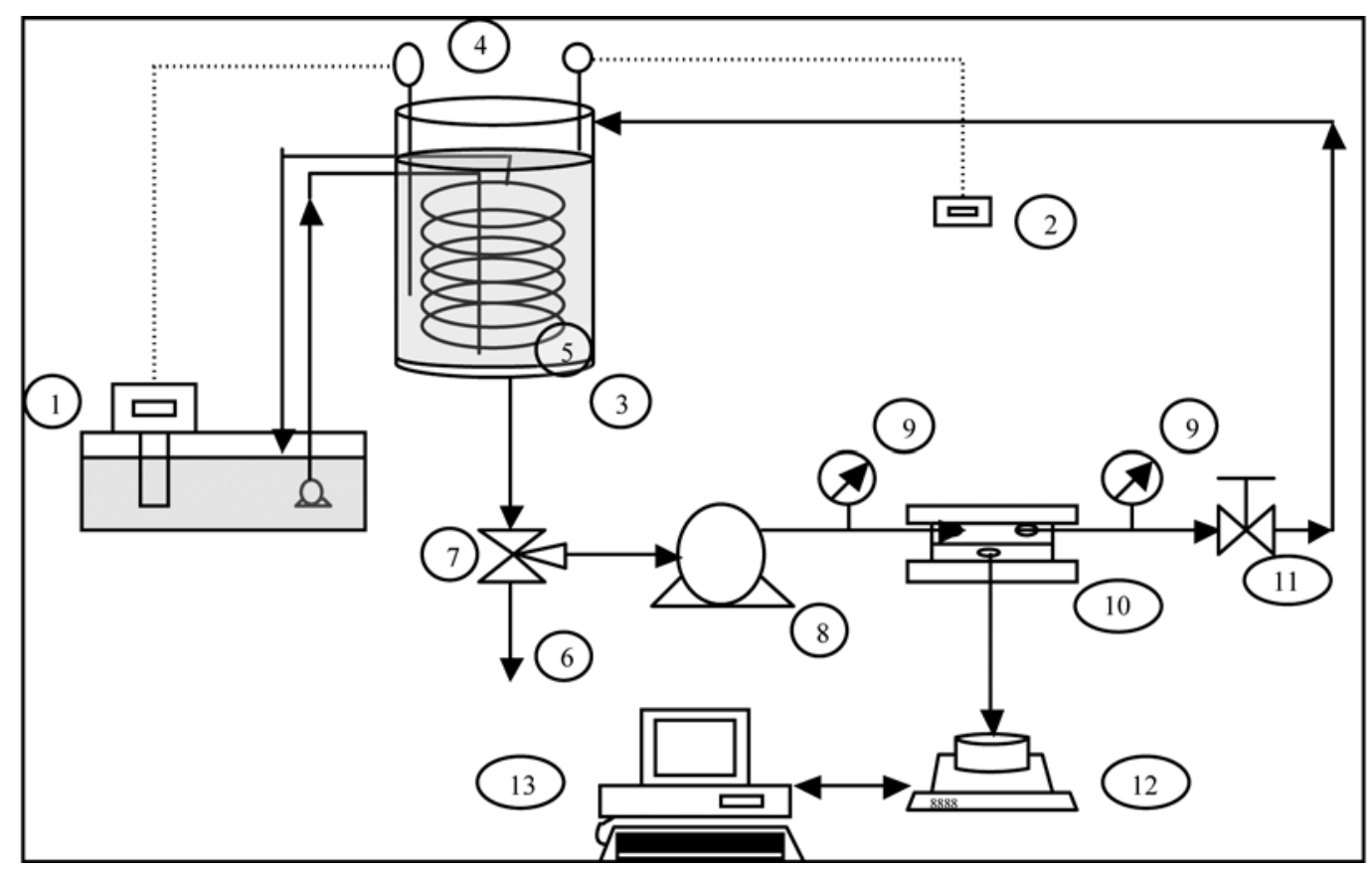

1- Circulating thermal bath, 2- Bill-poster temperature, 3- Feed tank, 4- Temperature probe, 5- Coil, 6- Purge, 7- Three-way valve, 8- High-pressure pump, 9- Manometer, 10- Sepa CF II Cell (Osmonics), 11- Pressure Control Valve, 12- Balance, 13- Personal computer

Fig. 2. Schematic diagram of the NF pilot. 
- Experimental validation using the selected membrane and operating conditions for the treatment of real wastewaters.

The experimental procedure followed during the test of the membranes included the following steps:

- Membrane conditioning: before using new membranes a conditioning step must be made to eliminate preservation products and to compact the membrane. Membrane is placed in the membrane cell and pure water is circulated through the membrane for 1 hour. Applied temperature and pressure $\left(30^{\circ} \mathrm{C}\right.$ and 17.5 bar) were higher than those in the normal operating conditions. This step was only carried out once when the membrane is new.

- Pure water permeability: after the conditioning step and after every test, pure water permeability was determined to ensure about the membrane stability and integrity. These measurements were performed using demineralised water.

- Flow and rejection measurements for several feed wastewaters (fixed operating conditions): when the desired temperature was reached, the feed was circulated and the pressure increased step by step till the desired pressure was reached. The feed solution circulates at constant tangential velocity $(1,23 \mathrm{~m} / \mathrm{s})$, which allows to neglect concentration polarization effects in membrane surface. After around $5 \mathrm{~min}$ of circulation, it was assumed that the steady state was reached. The permeate fraction was re-circulated into the feed to keep the solution concentration constant. The permeate flux was determined from mass measurements. A sample was then collected to calculate rejection.

- Rejection calculation: collected samples in the previous step were analysed and results were compared with the feed samples analyses. Then rejection $(\%)$ were calculated according to the following equation:

$$
R=\left(1-\frac{C^{\text {permeate }}}{C^{f \text { eed }}}\right) * 100
$$

where $C^{\text {permeate }}$ and $C^{f \text { eed }}$ are the concentration of permeate and feed respectively.

\subsubsection{ANALYSES}

Conductivity and $\mathrm{pH}$ of solutions were determined using a conductimeter JF 340 WTW and a pHmeter PHN 81 Tacussel, respectively. Methods and equipment used to analyze the different parameters and species in the wastewaters are listed in table II:

\section{RESULTS AND DISCUSSION}

\subsection{Ceramic industry wastewater composition}

Wastewaters can be analysed using different parameters like $\mathrm{pH}$, conductivity and chemical oxygen demand (COD), these two parameters being indicative of total dissolved salts (TDS) and of the organic pollution, respectively. The hand operated cleaning usually made in ceramic industry and the large range of products entail a wide variability in composition. Table III shows the mean average values of the parameters describing the wastewater composition (8): $\mathrm{pH}$, conductivity, the more abundant ions and TDS and COD.

TABLE III. CERAMIC INDUSTRY WASTEWATER COMPOSITION

\begin{tabular}{|c|c|}
\hline Parameter & Variation interval \\
\hline $\mathrm{pH}$ & $7-9$ \\
\hline Conductivity $(\mu \mathrm{S} / \mathrm{cm})$ & $2000-5000$ \\
\hline Chlorides $(\mathrm{mg} / \mathrm{L})$ & $100-1100$ \\
\hline Sulphates $(\mathrm{mg} / \mathrm{L})$ & $100-1000$ \\
\hline Calcium $(\mathrm{mg} / \mathrm{L})$ & $50-500$ \\
\hline Magnesium $(\mathrm{mg} / \mathrm{L})$ & $10-100$ \\
\hline Sodium $(\mathrm{mg} / \mathrm{L})$ & $50-750$ \\
\hline Boron $(\mathrm{mg} / \mathrm{L})$ & $1-75$ \\
\hline TDS $(\mathrm{mg} / \mathrm{L})$ & $300-3700$ \\
\hline COD $\left(\mathrm{mg} \mathrm{O}_{2} / \mathrm{L}\right)$ & $100-1300$ \\
\hline
\end{tabular}

\subsection{NanoFlux prediction}

As above-mentioned NanoFlux computer simulation programme allows us to predict the performances of NF membranes for permeation of neutral and charged species. Model solutions containing two neutral solutes of different molecular size were chosen for mimicking the removal of organic matter from the wastewaters. As an example, Table IV gives the predicted rejection data for permeation of two neutral species (ethyl alcohol and poly(ethyleneglycol), PEG400) using two NF membranes (NF-90 and NF-200). It should be noted that PEG- derivatives are compounds of interest in the ceramic industry since they are used in the decoration stage of the tile manufacturing process. As it can be seen

TABLE II. METHODS AND EQUIPMENT FOR WASTEWATER ANALYSIS

\begin{tabular}{|c|c|c|}
\hline Parameter & Method & Equipment \\
\hline COD & UNE 77-004/89 & UV-160A Shimadzu \\
\hline $\mathrm{B}$ & Azometine-H method by UV-VIS spectophotometry & ICS-100 Dionex \\
\hline $\mathrm{SO}_{4}^{2-}$ and Cl & Ionic chromatography & 1100B Perkin Elmer \\
\hline $\mathrm{Na}^{+}, \mathrm{K}^{+}, \mathrm{Mg}^{2+}$ and Ca ${ }^{2+}$ & Atomic absorption spectrophotometry UNE 77-056 \\
\hline
\end{tabular}


TABLE IV. NANOFLUX PREDICTION FOR PERMEATION OF TWO NEUTRAL SPECIES (ETHYL ALCOHOL AND PEG-400) ON NF-90 AND NF-200 MEMBRANES.

\begin{tabular}{|c|c|c|c|c|c|}
\hline \multirow{2}{*}{ Membrane } & $\begin{array}{c}\text { Pressure } \\
(\mathbf{b a r})\end{array}$ & $\begin{array}{c}\text { Flux } \\
\left(\mathbf{L} / \mathbf{h} \cdot \mathbf{m}^{2}\right)\end{array}$ & Rejected species & Molar mass (g/mol) & $\begin{array}{c}\text { Rejection } \\
(\%)\end{array}$ \\
\hline \multirow{2}{*}{ NF-90 } & $<5$ & - & PEG-400 & 400 & 100 \\
\cline { 2 - 6 } & 5 & 23 & Ethyl alcohol & 46 & 80 \\
\hline \multirow{2}{*}{ NF-200 } & $<5$ & - & PEG-400 & 400 & 100 \\
\cline { 2 - 6 } & 5 & 25 & Ethyl alcohol & 46 & 62 \\
\hline
\end{tabular}

NanoFlux predicts that PEG 400 is $100 \%$ rejected by both membranes whereas a small molecule as ethyl alcohol is more significantly rejected by the NF-90 membrane

In the same way, prediction of membrane performances can be obtained for permeation of charged species. From the table III, it appears that a mixture of the anions $\mathrm{Cl}^{-}$and $\mathrm{SO}_{4}{ }^{2-}$ and the cations $\mathrm{Na}^{+}$and $\mathrm{Mg}^{2+}$ can give a good model solution of the studied wastewaters. Table V presents simulation data obtained for the two same membranes (NF-90 and NF-200) for a solution containing an equimolar mixture of $\mathrm{NaCl}$ and $\mathrm{MgSO}_{4}$ with a total salt concentration of $0.03 \mathrm{M}(2.69 \mathrm{~g} / 1)$.
Again the membrane NF-90 shows the better performances in rejecting the considered ions even at relatively low operating pressure (5 bar) and with similar permeate flux. It was then decided to validate the simulation by performing permeation of real wastewaters on NF-90.

\subsection{Results with real wastewaters of the ceramic industry}

The NF treatment was carried out at low pressure with wastewater samples collected in two different companies after the physico-chemical treatment stage. The operating conditions for both samples are summarized in table VI. $\left(^{*}\right)$

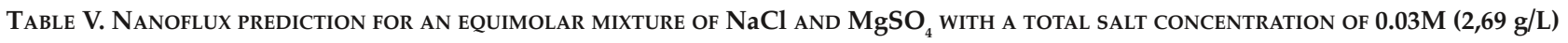

\begin{tabular}{|c|c|c|c|c|}
\hline Membrane & $\begin{array}{c}\text { Pressure } \\
\text { (bar) }\end{array}$ & $\begin{array}{c}\begin{array}{c}\text { Flux } \\
\left(\mathrm{L} / \mathrm{h} \cdot \mathrm{m}^{2}\right)\end{array} \\
\end{array}$ & Ions & $\begin{array}{c}\text { Rejection } \\
(\%)\end{array}$ \\
\hline \multirow{8}{*}{ NF-90 } & \multirow{4}{*}{5} & \multirow{4}{*}{23} & $\mathrm{Na}^{+}$ & 90 \\
\hline & & & $\mathrm{Cl}^{-}$ & 87 \\
\hline & & & $\mathrm{Mg}^{2+}$ & 97 \\
\hline & & & $\mathrm{SO}_{4}^{2-}$ & 100 \\
\hline & \multirow{4}{*}{11} & \multirow{4}{*}{60} & $\mathrm{Na}^{+}$ & 90 \\
\hline & & & $\mathrm{Cl}^{-}$ & 90 \\
\hline & & & $\mathrm{Mg}^{2+}$ & 100 \\
\hline & & & $\mathrm{SO}_{4}^{2-}$ & 100 \\
\hline \multirow{8}{*}{ NF-200 } & \multirow{4}{*}{5} & \multirow{4}{*}{27} & $\mathrm{Na}^{+}$ & 47 \\
\hline & & & $\mathrm{Cl}^{-}$ & 60 \\
\hline & & & $\mathrm{Mg}^{2+}$ & 85 \\
\hline & & & $\mathrm{SO}_{4}^{2-}$ & 98 \\
\hline & \multirow{4}{*}{11} & \multirow{4}{*}{75} & $\mathrm{Na}^{+}$ & 72 \\
\hline & & & $\mathrm{Cl}^{-}$ & 65 \\
\hline & & & $\mathrm{Mg}^{2+}$ & 94 \\
\hline & & & $\mathrm{SO}_{4}^{2-}$ & 100 \\
\hline
\end{tabular}


TABLE VI. OPERATING CONDITIONS USED IN TESTS WITH WASTEWATER SAMPLES

\begin{tabular}{|c|c|c|c|}
\hline Sample & $\begin{array}{c}\text { Pressure } \\
(\mathbf{b a r})\end{array}$ & $\begin{array}{c}\text { Temperature } \\
\left({ }^{\circ} \mathbf{C}\right)\end{array}$ & $\begin{array}{c}\text { Flux } \\
\left(\mathbf{L} /\left(\mathbf{h ~}^{\mathbf{2}} \mathbf{~ b a r}\right)\right)\end{array}$ \\
\hline wastewater 1 & 5 & 25 & 2,27 \\
\hline wastewater 2 & 4 & 25 & 3,45 \\
\hline
\end{tabular}

Table VII gathers the parameter data obtained for the two samples before and after the NF purification on NF-90 membrane. These results show a reduction of more than 90 $\%$ of the total dissolved salts (TDS). As expected, multivalent ions $\left(\mathrm{SO}_{4}^{2-}, \mathrm{Mg}^{2+}\right.$ and $\left.\mathrm{Ca}^{2+}\right)$ are almost totally rejected during the NF permeation. On the other hand, the monovalent ones $\left(\mathrm{Cl}^{-}, \mathrm{Na}^{+}\right.$and $\left.\mathrm{K}^{+}\right)$are about $90 \%$ rejected by the NF-90 membrane as predicted by the NanoFlux simulation software. When considering the COD parameter, it appears that the NF permeation permits an efficient removal of the organic pollution since this parameter gives values lower than 50 $\mathrm{mg} \mathrm{O}_{2} / 1$. This effect is particularly striking in the case of the higher loaded solution (wastewater 1 ) with a COD reduction of more than $90 \%$.

Finally, it has to be noted that these results were obtained only by using NanoFlux prediction and without any experimental optimisation of the process.

\section{CONCLUSIONS}

Advanced process based on membrane separation technique may be useful to ceramic industry to improve management of their wastewaters. This improvement can allow to companies a greater reusability of treated wastewaters giving rise to important economic savings and reducing the environmental impact.

Experimental findings obtained in this study show that NF can be a good technique of purification of ceramic industry wastewaters because a very significant total dissolved salts (TDS) and COD reduction (retention values of about 90\%) is achieved. On the other hand, these results also prove that NanoFlux is a good tool of prediction that can save time and money in experimental studies, because predictions done by the program are quite next to the results obtained experimentally.

\section{ACKNOWLEDGMENTS}

The authors wish to thank the Valencian Institute of Small and Medium-Sized Enterprises (IMPIVA) in Comunidad Valenciana (Spain) and Eureka Program for its financial help (IMAETA/2005/11, IMIDIE/2009/3 and $\sum$ !4121).

TAble VII. Purification data of WASTEWATERS using NANOFILTRATION ON NF-90 MEMBRANE

\begin{tabular}{|c|c|c|c|c|c|c|}
\hline \multirow{3}{*}{ Analysed parameters } & \multicolumn{3}{|c|}{ Wastewater 1} & \multicolumn{3}{|c|}{ Wastewater 2} \\
\hline & \multirow{2}{*}{$\begin{array}{c}\text { After physico- } \\
\text { chemical } \\
\text { treatment }\end{array}$} & \multicolumn{2}{|c|}{$\begin{array}{l}\text { After NF treatment with } \\
\text { NF90/5 bar }\end{array}$} & \multirow{2}{*}{$\begin{array}{c}\text { After physico- } \\
\text { chemical } \\
\text { treatment }\end{array}$} & \multicolumn{2}{|c|}{$\begin{array}{l}\text { After NF treatment with } \\
\text { NF90/4 bar }\end{array}$} \\
\hline & & Analyses & Rejection & & Analyses & Rejection \\
\hline $\mathrm{pH}$ & 8,35 & 7,44 & - & 7,95 & 7,03 & - \\
\hline Conductivity (mS/cm) & 3,5 & 0,16 & $95 \%$ & 2,33 & 0,17 & $93 \%$ \\
\hline B (mg/L) & 5,9 & 3,9 & $34 \%$ & 3,6 & 2,8 & $22 \%$ \\
\hline $\mathrm{SO}_{4}{ }^{2-}(\mathrm{mg} / \mathrm{L})$ & 258 & $<10$ & $>96 \%$ & 304 & $<10$ & $>97 \%$ \\
\hline $\mathrm{Cl}^{-}(\mathrm{mg} / \mathrm{L})$ & 932 & 36 & $96 \%$ & 619 & 41 & $93 \%$ \\
\hline $\mathrm{Na}^{+}(\mathrm{mg} / \mathrm{L})$ & 555 & 28,4 & $95 \%$ & 304 & 30,4 & $90 \%$ \\
\hline $\mathrm{K}^{+}(\mathrm{mg} / \mathrm{L})$ & 16,8 & 0,9 & $95 \%$ & 18,8 & 2,1 & $89 \%$ \\
\hline $\mathrm{Mg}^{2+}(\mathrm{mg} / \mathrm{L})$ & 28 & 0,3 & $99 \%$ & 24,8 & 0,3 & $99 \%$ \\
\hline $\mathrm{Ca}^{2+}(\mathrm{mg} / \mathrm{L})$ & 75 & $<0.1$ & $>99 \%$ & 101 & $<0.1$ & $>99 \%$ \\
\hline COD (mg/L) & 1156 & 44 & $96 \%$ & 129 & $<30$ & $>77 \%$ \\
\hline
\end{tabular}




\section{REFERENCES}

(1) MULDER, M. Basic principles of membrana technology, $2^{\text {nd }}$ Dordrecht: Kluwer Academic Publishers, 1996

(2) Van der BRUGGEN, B.; VANDECASTEELE, C.; Van GESTEL, T. DOYEN,W. ; R. LEYSEN, R. A review of pressure-driven membrana processes in wasterwater treatment and drinking water production, Environ.Prog., 22(1), 46-56, 2003.

(3) BAKER, R. W. Membrana technology and applications, $2^{\text {nd }}$. Chichester: John Wiley \& Sons, Ltd. 2004.

(4) GUIZARD, C. Guide de la Nanofiltration. Montpellier : Club Français des Membranes, 2000.

(5) PALMERI, J.; SANDEAUX, J.; SANDEAUX, R. et al. Modeling of multielectrolyte transport in charged ceramic and organic nanofilters using the computer simulation program NANOFLUX. Desalination, 147, 231- 236, 2002.

(6) LEFEBVRE, X.; PALMERI, J.; SANDEAUX, J., et al. Nanofiltration Modeling: a comparative study of the salt filtration performance of charged ceramic and organic membranas using the computer simulation program NANOFLUX. Sep. Purif. Technol., 32, 117-126, 2003.

(7) LEFEBVRE, X.; PALMERI, J.; DAVID, P. Nanofiltration theory: an analytic approach for single salts, J. Phys. Chem. B, 108, 16811-16824, 2004.

(8) BLASCO, A. et al. Tratamiento de emisiones gaseosas, efluentes líquidos y residuos sólidos de la industria cerámica. Castellón: Ed. AICE-ITC, 1991.

Recibido: 01/03/2012

Aceptado: $11 / 04 / 2012$ 